\title{
KAJI PERFORMANSI REFRIGERAN R-290, R-32, DAN R-410A SEBAGAI ALTERNATIF PENGGANTI R-22
}

\author{
R. Ufie ${ }^{1, *}$, C. S. E Tupamahu², S. J. E. Sarwuna ${ }^{3}$, Jufraet Frans ${ }^{4}$ \\ 1Jurusan Teknik Mesin Fakultas Teknik Universitas Pattimura, Ambon 97233 \\ *Email: rikhardufienew@gmail.com \\ 2Jurusan Teknik Mesin Fakultas Teknik Universitas Pattimura, Ambon 97233 \\ Email: tupamahucendy@gmail.com \\ 3Jurusan Teknik Mesin Fakultas Teknik Universitas Pattimura, Ambon 97233 \\ Email: etwansarwuna19@gmail.com \\ 4Jurusan Teknik Mesin Fakultas Teknik Universitas Pattimura, Ambon 97233 \\ Email: jufraet f@gmail.com
}

\begin{abstract}
Abstrak. Refrigeran R-22 termasuk bahan perusak lapisan ozon, sehingga dalam bidang pengkondisian udara mulai diganti antara lain dengan refrigeran R-32 dan R-410a, dan juga R-290. Melalui penelitian ini hendak diketahui berapa besar Coefficient of Performance (COP) dan Kapasitas Refrigerasi (Qe) yang dapat dihasilkan untuk keempat jenis refrigeran tersebut. Kajian dilakukan secara teoritik untuk kondisi kerja siklus kompresi uap dengan temperatur evaporasi (Tevap) sebesar $0,-5$, dan $-10^{\circ} \mathrm{C}$, temperatur refrigeran dipanaskan lanjut $(\triangle \mathrm{TSH})$ sebesar $5{ }^{\circ} \mathrm{C}$, temperatur kondensasi (Tkond) $45^{\circ} \mathrm{C}$ dan temperatur refrigeran bawah-dingin $(\triangle \mathrm{TSC}) 10^{\circ} \mathrm{C}$ dan daya kompresi sebesar 1 PK. Hasil kajian menunjukkan bahwa Coefficient of Performance (COP) pada penggunaan R-22 dan R-290 lebih tinggi dibandingkan pada penggunaan R-32 dan R410a, yaitu masing-masing sebesar 4,$920 ; 4,891 ; 4,690$ dan 4,409 jika bekerja pada temperatur evaporasi sebesar $0{ }^{\circ} \mathrm{C} ; 4,260 ; 4,234 ; 4,060$ dan 3,812 jika bekerja pada temperatur evaporasi sebesar $-{ }^{\circ}{ }^{\circ} \mathrm{C}$; dan sebesar 3,$730 ; 3,685 ; 3,550$ dan 3,324 jika bekerja pada temperatur evaporasi sebesar $-10{ }^{\circ} \mathrm{C}$. Berdasarkan besar COP tersebut, jika instalasi ini bekerja dengan daya kompresi $1 \mathrm{PK}$, maka kapasitas pendinginan (Cooling Capacity) pada penggunaan R-22 dan R-290 lebih tinggi dibandingkan pada penggunaan R-32 dan R-410a, yaitu masing-masing sebesar 3,617 kW ; 3,597 kW; 3,449 kW dan $3,243 \mathrm{~kW}$. Jika bekerja pada temperatur evaporasi sebesar $0{ }^{\circ} \mathrm{C} ; 3,133 \mathrm{~kW} ; 3,114 \mathrm{~kW}$; $2,986 \mathrm{~kW}$ dan $2,804 \mathrm{~kW}$ jika bekerja pada temperatur evaporasi sebesar $-5{ }^{\circ} \mathrm{C}$; dan sebesar $2,741 \mathrm{~kW} ; 2,710 \mathrm{~kW} ; 2,611 \mathrm{~kW}$ dan $2,445 \mathrm{~kW}$ jika bekerja pada temperatur evaporasi sebesar $-10^{\circ} \mathrm{C}$.
\end{abstract}

Kata kunci: Perbandingan Refrigeran, R-22, R-32, R-290; R-410a, COP, Kapasitas refrigerasi.

Abstract. Refrigerant $R-22$ is a substance that destroys the ozone layer, so that in the
field of air conditioning it has begun to be replaced, among others with refrigerants $R-32$
and $R-410$, and also $R-290$. Through this research, we want to know how much
Coefficient of Performance (COP) and Refrigeration Capacity $(Q e)$ can be produced for
the four types of refrigerants. The study was carried out theoretically for the working
conditions of the vapor compression cycle with an evaporation temperature (Tevap) of 0 ,
-5 , and $-10^{\circ} C$, a further heated refrigerant temperature $(\triangle T S H)$ of $5{ }^{\circ} C$, a condensation
temperature (Tkond) of 45 oC and a low-cold refrigerant temperature. $(\Delta T S C) 10^{\circ} C$ and
compression power of $1 P K$. The results of the study show that the Coefficient of
Performance (COP) in the use of $R-22$ and $R-290$ is higher than the use of $R-32$ and $R-$
$410 a$, which are 4,920 respectively; 4,$891 ; 4.690$ and 4.409 when working at an
evaporation temperature of $0{ }^{\circ} C ; 4.260 ; 4,234 ; 4.060$ and 3.812 when working at an
evaporation temperature of $-5{ }^{\circ} C ;$ and amounted to 3,$730 ; 3,685 ; 3,550$ and 3,324 if
working at an evaporation temperature of $-10{ }^{\circ} C$. Based on the size of the COP, if this
installation works with a compression power of 1 PK, then the cooling capacity of the $R$ - 
22 and $R-290$ is higher than the $R-32$ and $R-410 a$, which are 3,617 respectively. $k W$; $3,597 \mathrm{~kW} ; 3,449 \mathrm{~kW}$ and 3,243 $\mathrm{kW}$. If working at an evaporation temperature of $0{ }^{\circ} \mathrm{C}$; $3.133 \mathrm{~kW} ; 3.114 \mathrm{~kW} ; 2,986 \mathrm{~kW}$ and 2,804 $\mathrm{kW}$ if working at an evaporation temperature of $-5 \mathrm{oC}$; and 2,741 kW;2,710 kW;2,611 kW and 2,445 $\mathrm{kW}$ if working at an evaporation temperature of $-10^{\circ} \mathrm{C}$.

Keywords: Refrigeran, $R-22, R-32, R-290 ; R-410 a, C O P$, capacity refrigeration.

\section{PENDAHULUAN}

Sejak ditetapkannya Protokol Montreal 1987 yang diikuti berbagai amandemennya, secara internasional terus dilakukan pembatasan dan penghapusan secara bertahap (phase-out) penggunaan jenis refrigeran yang termasuk dalam bahan perusak lapisan ozon dan juga upaya penggantian refrigeran baik yang sifatnya drop in substitute maupun jenis refrigeran dengan instalasi yang baru. Salah satu jenis refrigeran yang termasuk dalam kategori bahan perusak lapisan ozon yakni R-22 (Hydroclorofluorocarbon, HCFC-22) yang banyak digunakan pada unit pengkondi-sian udara [1]. Refrigeran R-22 ini diketahui memiliki indek ODP (Ozone Depleting Potential) sebesar 0,05 dan juga indeks GWP (Global Warming Potential) sebesar 1800.

Sesuai Peraturan Menteri Perdagangan RI No. 55/M-DAG/PER/ 9/1014, semua barang berbasis sistem pendingin yang menggunakan refrigeran ini baik dalam keadaan terisi maupun kosong dilarang untuk diimpor sejak tanggal 1 januari 2015. Ini berarti unit pendingin R-22 dengan berbagai merek tidak lagi diperbolehkan untuk diimpor, walau instalasi yang ada masih ada tetap diizinkan untuk digunakan, menuju penghapusan total refrigeran ini pada januari 2030.

Mengingat penggunaan instalasi pendingin $\mathrm{R}$ 22 yang cukup luas, maka telah dilakukan upaya pencarian refrigeran pengganti untuk dapat digunakan pada instalasi dimaksud antara lain dikenal dengan nama HCR-22 dan Musicool-22. Kedua Refrigeran ini berbasis bahan propana (R290) dan natural butane (R-400 dan R-400a) dan memiliki keunggulan yakni bersifat drop-in substitute yaitu dapat digunakan secara langsung tanpa penggantian komponen utama sistem refrigerasi yang ada [2]. Kaji eksperimental terhadap jenis refrigeran Hycool HCR-22 sebagai alternatif pengganti R-22 [3], dimana ditemukan bahwa nilai Coefficient of Performance (COP) dari refrigerant $\mathrm{R}-22$ rata-rata masih lebih tinggi dari Hycool HCR-22.

Akhir-akhir ini mulai diperkenalkan penggunaan refrigeran berbasis R-290 [4][5][6], penggunaan refrigeran R-32 [7] dan R-410a sebagai instalasi pendingin [8]. Refrigeran R-410a diperkenalkan sebagai refrigeran yang ramah lingkungan yaitu karena memiliki ODP $=0$ walaupun GWP masih cukup tinggi yaitu sebesar 2090, sedangkan berdasar pada cooling index diklaim bahwa R-32 lebih unggul dibanding R-22, selain sifatnya yang ramah lingkungan $(\mathrm{ODP}=0$ dan GWP = 675) walau termasuk dalam jenis refrigeran yang mudah terbakar [9].

Dalam penelitian ini dilakukan kajian teoritik untuk membandingkan besar nilai COP dari keempat jenis refrigeran yakni R-22, R-32, R-290 dan R-410a untuk kondisi kerja siklus kompresi uap yang sama dan menilai manakah di antara keempat refrigeran tersebut yang memberi kapasitas refrigerasi yang tertinggi untuk daya kompresi yang sama. Kajian ini dipandang perlu untuk mendapatkan penilaian berdasar sudut pandang termodinamika terlepas dari berbagai klaim yang diajukan para produsen. Penelitian ini dilakukan pada Lab. Teknik Pendingin dan Pengkondian Udara Fakultas Teknik Universitas Pattimura

\section{BAHAN DAN METODE}

\subsection{Kondisi Kajian}

Kajian dilakukan untuk penggunaan refrigeran R-22，R-32，R-290, dan R410a, masing-masing pada unit pengkondisian udara dengan daya kompresi sebesar 1 PK atau setara dengan $0,7355 \mathrm{~kW}$, yang diandaikan bekerja pada kondisi sebagai berikut:

a) Temperatur evaporasi (Tevap), sebesar $0{ }^{\circ} \mathrm{C}$, $-5^{\circ} \mathrm{C}$, dan $-10{ }^{\circ} \mathrm{C}$.

b) Kenaikan temperatur refrigeran akibat pemanasan lanjut sebelum memasuki kompresor $(\triangle \mathrm{TSH})$, sebesar $5^{\circ} \mathrm{C}$.

c) Temperatur evaporasi sebesar $45^{\circ} \mathrm{C}$.

d) Penurunan temperatur refrigeran akibat pendinginan lanjut (bawah-dingin) sebelum memasuki peralatan ekspansi $(\triangle \mathrm{TSC})$, sebesar $10^{\circ} \mathrm{C}$.

e) Efisiensi isentropik kompresor ( sebesar 0,95 


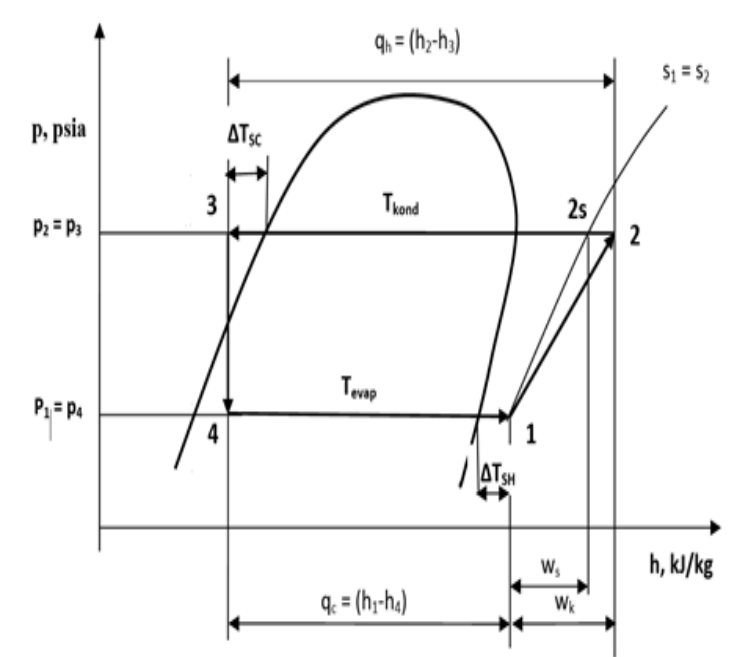

Gambar 1. Kondisi kajian sesuai skema diagram tekanan-entalpi (p-h)

\subsection{Prosedur Perhitungan}

Perhitungan dilakukan untuk penggunaan refrigeran R-22, R-32, R-290, dan R-410a, masing-masing untuk tiga kondisi kerja, yaitu pada temperatur evaporasi sebesar $0 \mathrm{oC},-5 \mathrm{oC}$ dan -10 oC, dengan prosedur sebagai berikut:

a) Sesuai besar temperatur evaporasi ditentukan lebih dulu besar tekanan evaporasi $(\mathrm{p} 1=\mathrm{p} 4)$ dan tekanan kondensasi $(\mathrm{p} 2=\mathrm{p} 3)$ sesuai data sifat refrigeran yang bersangkutan.

b) Berdasarkan tekanan evaporasi dan kenaikan temperatur evaporasi pada proses pemanasan lanjut $(\triangle \mathrm{TSH})$, ditetapkan temperatur refrigeran pada tingkat keadaan 1 yakni saat memasuki kompresor $(\mathrm{T} 1=$ Tevap $+\Delta \mathrm{TSH})$.

c) Berdasarkan tekanan kondensasi dan penurunan temperatur evaporasi pada proses pendinginan lanjut $(\triangle \mathrm{TSC})$, ditetapkan temperatur refrigeran pada tingkat keadaan 3 yakni saat memasuki peralatan ekspansi (T3 $=$ Tkond $-\Delta \mathrm{TSC}$ ).

d) Dengan mengikuti garis entropi konstan yang ditarik dari tingkat keadaan 1, selanjutnya ditetapkan tingkat keadaan 2s pada perpotongan garis ini dengan garis tekanan evaporasi $(\mathrm{s} 1=\mathrm{s} 2 \mathrm{~s})$.

e) Untuk tiap tingkat keadaan, selanjutnya dicari nilai entalpi $(\mathrm{h} 1, \mathrm{~h} 2 \mathrm{~s}$, dan $\mathrm{h} 3=\mathrm{h} 4)$ yakni masing-masing untuk tingkat keadaan 1,2 s, dan 3 .

f) Selanjutnya dilakukan perhitungan nilai entalpi (h2) pada tingkat keadaan 2, dengan persamaan:

$$
h_{2}=h_{1}+\left(h_{2 s}-h_{1}\right) / \eta i s
$$

g) Berdasarkan nilai entalpi untuk tiap tingkat keadaan dilakukan perhitungan besar dampak refrigerasi (qo), Ashrae [10]
$q_{0}=h_{1}-h_{4}(\mathrm{~kJ} / \mathrm{kg})$

Kerja kompresi isentropik spesifik (ws), Ashrae [10]

$w_{s}=h_{2}-h_{1}$

laju alir massa refrigeran (m), Ashrae [10]

$\dot{m}_{\text {ref }}=\frac{q_{e}}{h_{1}-h_{4}}(\mathrm{~kg} / \mathrm{s})$

kerja kompresi aktual spesifik (wk), Ashrae [10]

$w_{k}=m_{r e f} \cdot w_{s}$

kalor spesifik yang dilepas kondensor (qk), Ashrae [10]

$q_{k}=m_{r e f} \cdot q_{k}$

besar Coefficient of Performance (COP), Ashrae [10].

$C O P=\frac{q_{0}}{w_{k}}=\frac{h_{1}-h_{4}}{h_{2}-h_{1}}$

h) Sesuai hasil perhitungan Coefficient of Performance (COP) dan daya kompresi $(\mathrm{Wk})$, dihitung kapasitas refrigerasi (Qc) tiap refrigeran, Ashrae [10].

$Q_{c}=\dot{m}_{r e f}\left(h_{1}-h_{4}\right)$

\section{HASIL DAN PEMBAHASAN}

\subsection{Hasil}

Tabel 1. Hasil perhitungan dampak refrige-rasi $\left(\mathrm{q}_{0}\right)$ antara R-22, R-32, R-290 dan R410a.

\begin{tabular}{|c|c|c|c|c|c|}
\hline \multirow[t]{2}{*}{ No } & \multirow[t]{2}{*}{$\begin{array}{l}\text { Jenis } \\
\text { refri- } \\
\text { geran }\end{array}$} & \multicolumn{3}{|c|}{$\begin{array}{c}\text { Besar dampak refrigerasi }\left(\mathrm{q}_{\mathrm{o}}\right) \\
\text { sesuai variasi temperatur } \\
\text { evaporasi }\end{array}$} & \multirow{2}{*}{$\begin{array}{l}\text { Sat } \\
{ }^{\circ} \mathrm{C}\end{array}$} \\
\hline & & 0 & -5 & -10 & \\
\hline 1 & R-22 & 165.7200 & 163.7300 & 161.6800 & $\mathrm{~kJ} / \mathrm{kg}$ \\
\hline 2 & & & & 253. & $\mathrm{~kJ} / \mathrm{kg}$ \\
\hline 3 & & & & & $\mathrm{~kJ} / \mathrm{kg}$ \\
\hline 4 & R-410a & 161.9700 & 160.1800 & 158.2600 & $\mathrm{~kJ} / \mathrm{kg}$ \\
\hline
\end{tabular}

Tabel 2. Hasil perhitungan perbandingan laju alir massa refrigeran $(\mathrm{m})$

\begin{tabular}{|c|c|c|c|c|c|}
\hline \multirow[t]{2}{*}{ No } & \multirow[t]{2}{*}{$\begin{array}{l}\text { Jenis } \\
\text { refri- } \\
\text { geran }\end{array}$} & \multicolumn{3}{|c|}{$\begin{array}{c}\text { Besar laju alir massa }(\mathrm{m}) \\
\text { sesuai variasi temperatur } \\
\text { evaporasi }\end{array}$} & \multirow{2}{*}{$\begin{array}{l}\text { Sat } \\
{ }^{\circ} \mathrm{C}\end{array}$} \\
\hline & & 0 & -5 & -10 & \\
\hline 1 & R-22 & 0,022 & 0,019 & 0,017 & $\mathrm{~kg} / \mathrm{s}$ \\
\hline 2 & R-32 & 0,013 & 0,012 & 0,010 & $\mathrm{~kg} / \mathrm{s}$ \\
\hline 3 & R-290 & 0,012 & 0,011 & 0,010 & $\mathrm{~kg} / \mathrm{s}$ \\
\hline 4 & R-410a & 0,020 & 0,018 & 0,015 & $\mathrm{~kg} / \mathrm{s}$ \\
\hline
\end{tabular}


Tabel 3. Hasil perhitungan perbandingan besar kerja kompresi spesifik (wk)

\begin{tabular}{|c|c|c|c|c|c|}
\hline \multirow[t]{2}{*}{ No } & \multirow[t]{2}{*}{$\begin{array}{l}\text { Jenis } \\
\text { refri- } \\
\text { geran }\end{array}$} & \multicolumn{3}{|c|}{$\begin{array}{c}\text { Besar kerja kompresi spesifik } \\
\text { (wk) sesuai variasi } \\
\text { temperatur evaporasi }\end{array}$} & \multirow{2}{*}{$\begin{array}{l}\text { Sat } \\
{ }^{\circ} \mathrm{C}\end{array}$} \\
\hline & & 0 & -5 & -10 & \\
\hline 1 & R-22 & 0,7355 & 0,7355 & 0,7355 & $\mathrm{~kg} / \mathrm{s}$ \\
\hline 2 & R-32 & 0,7355 & 0,7355 & 0,7355 & $\mathrm{~kg} / \mathrm{s}$ \\
\hline 3 & R-290 & 0,7355 & 0,7355 & 0,7355 & $\mathrm{~kg} / \mathrm{s}$ \\
\hline 4 & $\mathrm{R}-410 \mathrm{a}$ & 0,7355 & 0,7355 & 0,7355 & $\mathrm{~kg} / \mathrm{s}$ \\
\hline
\end{tabular}

Tabel 4. Hasil perhitungan perbandingan besar kalor yang dilepas kondensor (qk)

\begin{tabular}{|c|c|c|c|c|c|}
\hline \multirow[t]{2}{*}{ No } & \multirow[t]{2}{*}{$\begin{array}{l}\text { Jenis } \\
\text { Refri- } \\
\text { geran }\end{array}$} & \multicolumn{3}{|c|}{$\begin{array}{c}\text { Besar kalor yang dilepas } \\
\text { kondensor }\left(\mathrm{q}_{\mathrm{k}}\right) \text { sesuai variasi } \\
\text { temperatur evaporasi }\end{array}$} & \multirow{2}{*}{$\begin{array}{l}\text { Sat } \\
{ }^{\circ} \mathrm{C}\end{array}$} \\
\hline & & 0 & -5 & -10 & \\
\hline 1 & R-22 & 197,73 & 200,25 & 202,89 & $\mathrm{~kg} / \mathrm{s}$ \\
\hline 2 & R-32 & 308,48 & 314,97 & 321,70 & $\mathrm{~kJ} / \mathrm{kg}$ \\
\hline 3 & R-290 & 347,32 & 349,13 & 351,20 & $\mathrm{~kg} / \mathrm{s}$ \\
\hline 4 & R-410a & 196,87 & 200,10 & 203,49 & $\mathrm{~kJ} / \mathrm{kg}$ \\
\hline
\end{tabular}

Tabel 5. Hasil perhitungan perbandingan besar COP

\begin{tabular}{clcccc}
\hline No & $\begin{array}{l}\text { Jenis } \\
\text { refri- } \\
\text { geran }\end{array}$ & \multicolumn{4}{c}{ Pesar Coefficient of } \\
variasi temperatur evaporasi & Sat \\
& & 0 & -5 & -10 & ${ }^{\circ} \mathrm{C}$ \\
\hline 1 & R-22 & 4,92 & 4,26 & 3,73 & $\mathrm{~kg} / \mathrm{s}$ \\
2 & R-32 & 4,690 & 4,060 & 3,550 & $\mathrm{~kJ} / \mathrm{kg}$ \\
3 & R-290 & 4,891 & 4,234 & 3,685 & $\mathrm{~kg} / \mathrm{s}$ \\
4 & R-410a & 4,409 & 3,812 & 3,324 & $\mathrm{~kJ} / \mathrm{kg}$ \\
\hline
\end{tabular}

Tabel 6. Hasil perhitungan perbandingan kapasitas refrigerasi $(\mathrm{Qc}$

\begin{tabular}{llcccc}
\hline No & $\begin{array}{c}\text { Jenis } \\
\text { refri- } \\
\text { geran }\end{array}$ & $\begin{array}{c}\text { Besar kapasitas pendinginan } \\
\text { sesuai variasi temperatur } \\
\text { evaporasi }\end{array}$ & Sat \\
& & 0 & -5 & -10 & ${ }^{\circ} \mathrm{C}$ \\
\hline 1 & R-22 & 3.617 & 3.133 & 2.741 & $\mathrm{~kW}$ \\
2 & R-32 & 3.449 & 2.986 & 2.611 & $\mathrm{~kW}$ \\
3 & R-290 & 3.597 & 3.114 & 2.710 & $\mathrm{~kW}$ \\
4 & R-410a & 3.243 & 2.804 & 2.445 & $\mathrm{~kW}$ \\
\hline
\end{tabular}

\subsection{Pembahasan}

\section{- Perbandingan Besar Dampak Refrigerasi}

Perbandingan besar dampak refrigerasi antara refrigeran R-22, R-32, R-290 dan R-410a sesuai hasil perhitungan pada Tabel 1, ditunjukan secara grafik pada Gambar 2.

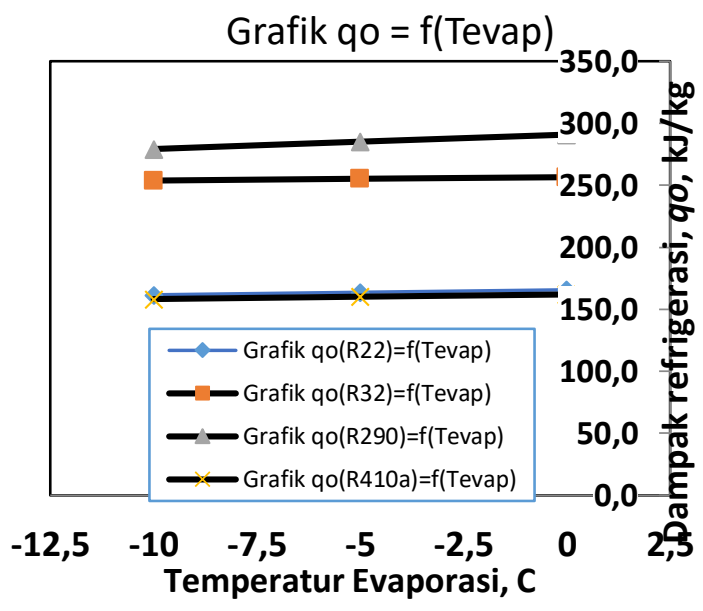

Gambar 2. Grafik perbandingan besar dampak refrigerasi

Sesuai Gambar 2, terlihat bahwa dampak refrigerasi pada penggunaan refrigeran R-290 dan R-32 lebih tinggi dibandingkan dengan pada penggunaan refrigeran R-22 dan R-410a. Oleh karena dampak refrigerasi ini dihitung sebagai selisih antara besar entalpi antara tingkat keadaan 1 dan tingkat keadaan $4(\mathrm{qo}=\mathrm{h} 1-\mathrm{h} 4)$, maka hal ini semata-mata tergatung pada sifat refrigeran yang bersangkutan. Untuk tiap refrigeran terlihat pula bahwa dampak refrigerasi semakin membesar dengan meningkatnya temperatur evaporasi.

\section{- Perbandingan Besar Laju Alir Massa Refrigerant}

Perbandingan besar laju alir massa refrigeran antara refrigeran R-22, R-32, R-290 dan R-410a sesuai hasil perhitungan pada Tabel 2, ditunjukan secara grafik pada Gambar 3 .

Gambar 3, terlihat bahwa laju alir massa refrigerasi yang dibutuhkan pada penggunaan refrigeran R-22 dan R-410a lebih tinggi dibandingkan dengan pada penggunaan refrigeran R-32 dan R-290. Hal ini disebabkan karena pada beban pendinginan yang konstan laju alir massa refrigeran ini berbanding terbalik dengan dampak refrigerasi yang dihasilkan oleh tiap refrigeran.

Pada beban konstan, semakin kecil dampak refrigerasi akan berakibat pada semakin besar laju alir massa yang dibutuhkan. Kenyataan ini dapat dilihat dengan membandingkan grafik pada Gambar 2 dan Gambar 3. 


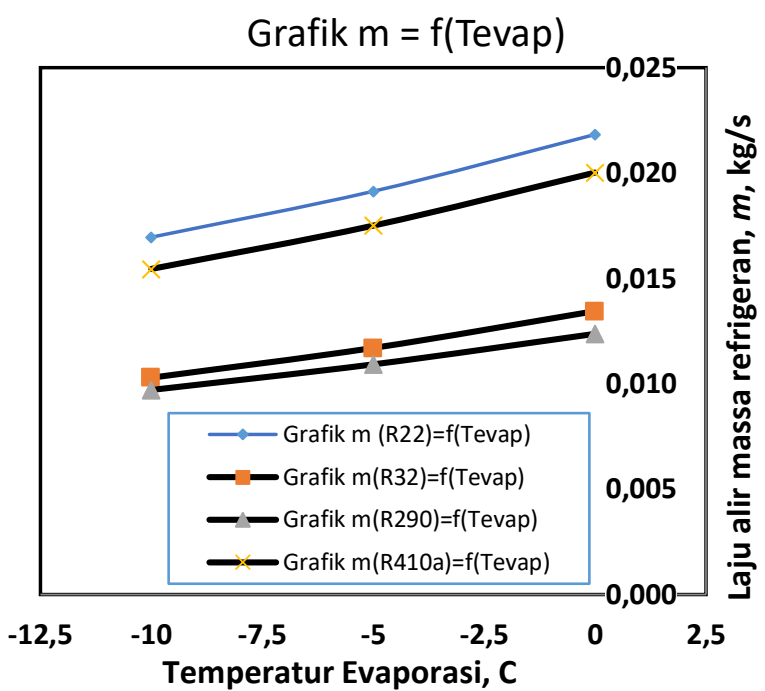

Gambar 3. Grafik perbandingan laju alir massa

- Perbandingan besar kerja kompresi (wk)

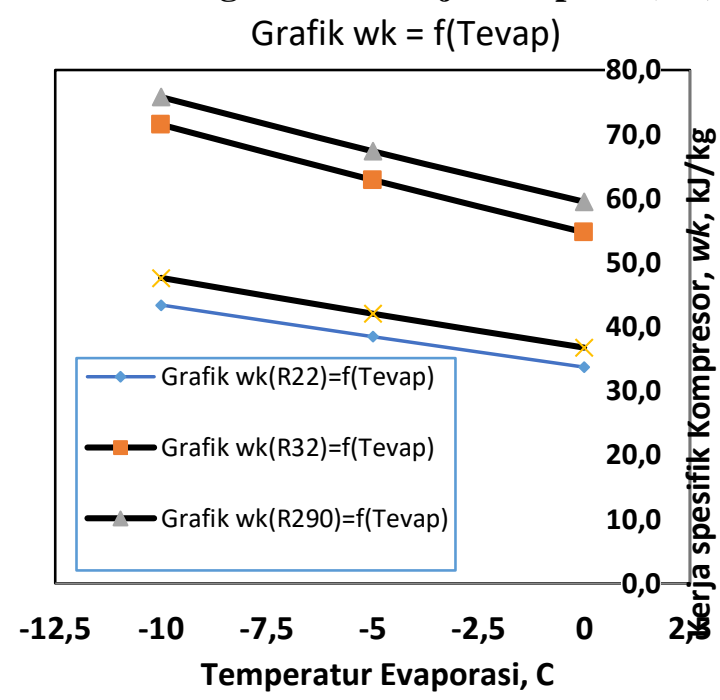

Gambar 4. Grafik perbandingan besar kerja kompresi

Perbandingan besar kerja kompresi spesifik (wk) yang diperlukan antara penggunaan refrigeran R-22, R-32, R-290 dan R-410a sesuai hasil perhitung-an pada Tabel 3, ditunjukan secara grafik pada Gambar 4.

Gambar 4, terlihat bahwa kerja kompresi spesifik pada penggunaan refrigeran R-290 dan R32 lebih tinggi dibandingkan dengan pada penggunaan refrigeran R-410a dan R-22. Oleh karena kerja kompresi spesifik ini dihitung sebagai selisih antara besar entalpi antara tingkat keadaan 2 dan tingkat keadaan $14(\mathrm{wk}=\mathrm{h} 2-\mathrm{h} 1)$.

\section{- Perbandingan besar kalor yang dilepaskan kondensor}

Perbandingan besar kalor yang dilepas kondensor antara refrigeran R-22, R-32, R-290 dan R-410a sesuai hasil perhitungan pada Tabel 4, ditunjukan secara grafik pada Gambar 5.

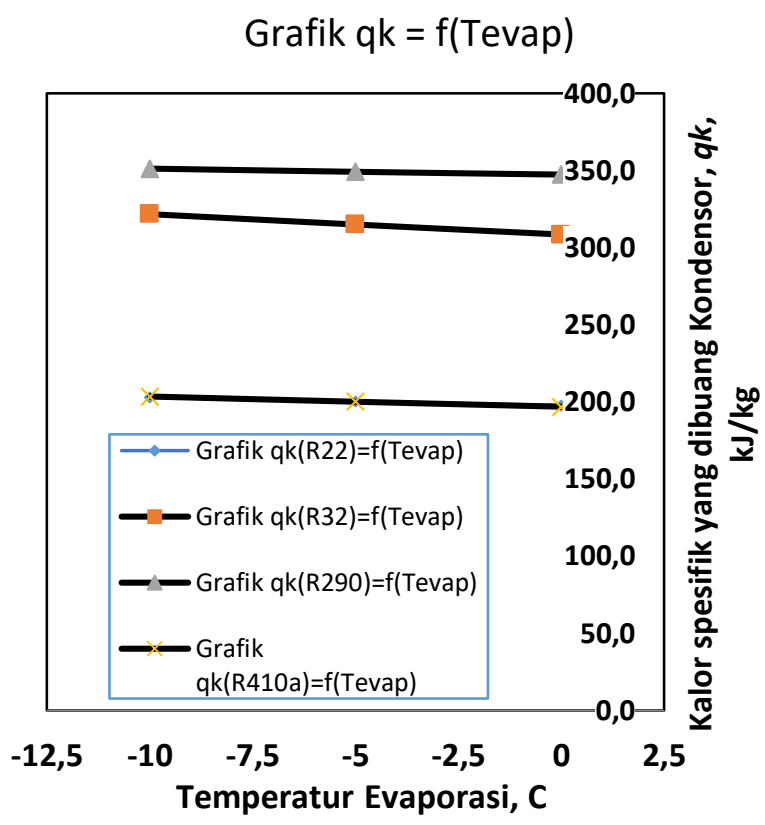

Gambar 5. Grafik perbandingan besar kalor yang dilepas kondensor

Sesuai Gambar 5, terlihat bahwa kalor yang harus dilepas oleh kondensor pada penggunaan refrigeran R-290 dan R-32 lebih tinggi dibandingkan dengan pada penggunaan refrigeran R-410a32 dan R-22. Dengan semakin kalor yang harus dilepas oleh kondensor maka semakin besar pula ukuran kondensor yang dibutuhkan. Terlihat pula bahwa untuk tiap refrigeran kerja kompresi spesifik yang dibutuhkan semakin membesar dengan meningkatnya temperatur evaporasi.

\section{- Perbandingan Besar COP}

Perbandingan besar Coefficient of Performance (COP) antara refrigeran R-22, R32, R-290 dan R-410a sesuai hasil perhitungan pada Tabel 5, ditunjukan secara grafik pada Gambar 6.

Sesuai Gambar 6, terlihat bahwa Coefficient of Performance (COP) pada penggunaan refrigeran R-22 dan R-290 lebih tinggi dibandingkan pada penggunaan refrigeran R-32 dan terakhir pada refrigeran R-410a. Oleh Coefficient of Performance (COP) ini merupakan perbandingan antara besar kapasitas pendinginan yang bisa dihasilkan terhadap daya kompresi $(\mathrm{COP}=$ Qc/Wk), maka untuk daya kompresi yang sama, refrigeran yang mempunyai nilai COP yang tinggi akan menghasilkan kapasitas pendinginan yang tinggi pula. Terlihat pula bahwa untuk tiap refrigeran nilai COP semakin membesar dengan meningkatnya temperatur evaporasi, walaupun 
untuk kepentingan pengkondisian udara maupun pendinginan produk, temperatur evaporasi harus dipertahankan pada harga yang relatif cukup rendah.

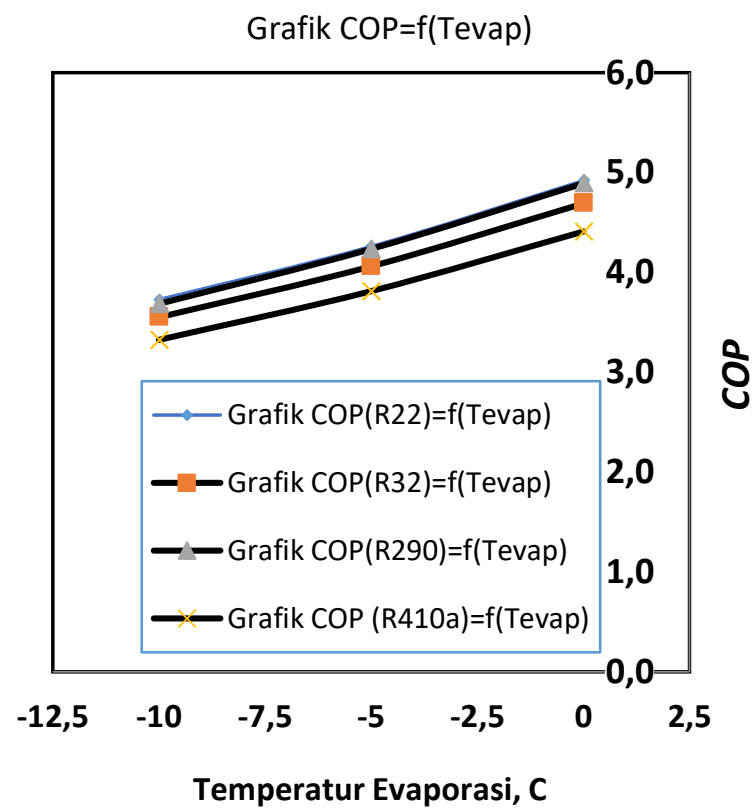

Gambar 6. Grafik perbandingan besar Coefficient of Performance (COP)

Hasil kajian ini menunjukkan kecenderungan yang sama dengan kaji eksperimental yang dilakukan oleh Priangkoso et al. pada AC Splik 1/2 PK dimana pada pengujian selama 120 menit diperoleh COP rata-rata untuk R-22 lebih tinggi dari R-32, dan R-410a, yaitu masing-masing sebesar 7,11, 5,23 dan 4,68. [11]. Hasil kajian Mahendra dkk, pada AC 2 HP juga menunjukkan bahwa R-22 memiliki COP yang lebih tinggi dari R-290 dan R-407C, masing-masing sebesar 4,408, 3,72 dan 4,086 [12].

\section{- Perbandingan Besar Kapasitas Pendinginan}

Perbandingan besar Kapasitas Pendinginan yang dapat dihasilkan antara refrigeran R-22, R32, R-290 dan R-410a sesuai hasil perhitungan pada Tabel 6, ditunjukan secara grafik pada Gambar 7. Sesuai Gambar 7, terlihat bahwa Kapasitas Pendinginan yang dapat dihasilkan pada penggunaan refrigeran R-22 dan R-290 lebih tinggi dibandingkan pada penggunaan refrigeran R-32 dan terakhir pada refrigeran R-410a. Sesuai persamaan untuk menghitung koefisien performansi, $\mathrm{COP}=\mathrm{Qc} / \mathrm{Wk}$, maka untuk daya kompresi yang sama dengan demikian penggunaan refrigeran R-22 dan R-290 akan menghasilkan kapasitas refrigerasi yang lebih besar dibanding pada penggunaan rR-32 dan R410 .

\section{Grafik Qc=f(Tevap)}

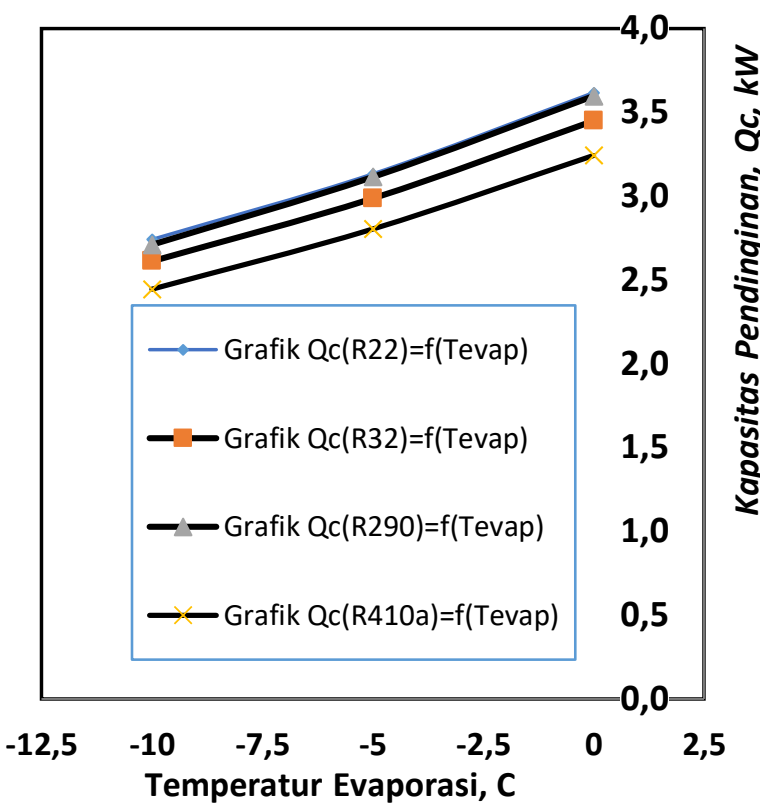

Gambar 7. Grafik perbandingan besar Kapasitas Pendinginan $(\mathrm{Qc})$ antara penggunaan refrigeran R-22, R-32, R-290 dan R$410 \mathrm{a}$, sesuai variasi temperatur evaporasi

Terlihat pula bahwa untuk tiap refrigeran kapasitas refrigerasi akan semakin membesar dengan meningkatnya temperatur evaporasi, walaupun sebagaimana telah dikemukakan, untuk kepentingan pengkondisian udara maupun pendinginan produk, temperatur evaporasi harus dipertahankan pada harga yang relatif cukup rendah.

\section{KESIMPULAN}

Sesuai hasil penelitian ini maka untuk unit pengkondian udara, dapatlah disimpulkan hal-hal sebagai berikut:

1. Coefficient of Performance (COP) pada penggunaan refrigeran R-22 dan R-290 lebih tinggi dibandingkan pada penggunaan refrigeran R-32 dan refrigeran R-410a. yaitu masing-masing sebesar 4,92;4,891; 4,690 dan 4,409 jika bekerja pada temperatur evaporasi sebesar $0{ }^{\circ} \mathrm{C} ; 4,260 ; 4,234 ; 4,060$ dan 3,812 jika bekerja pada temperatur evaporasi sebesar $-5{ }^{\circ} \mathrm{C}$; dan sebesar 3,$730 ; 3,685 ; 3,550$ dan 3,324 jika bekerja pada temperatur evaporasi sebesar $-10^{\circ} \mathrm{C}$.

2. Berdasarkan besar COP tersebut, maka jika tiap instalasi bekerja dengan daya kompresi 1 
PK $(0,7355 \mathrm{~kW})$ maka Kapasitas Pendinginan (Cooling Capacity) pada penggunaan refrigeran R-22 dan R-290 lebih tinggi dibandingkan pada penggunaan refrigeran $\mathrm{R}$ 32 dan terakhir pada refrigeran R-410a, yaitu masing-masing sebesar 3,617 kW ; 3,597 kW; $3,449 \mathrm{~kW}$ dan 3,243 $\mathrm{kW}$ jika bekerja pada temperatur evaporasi sebesar $0{ }^{\circ} \mathrm{C} ; 3,133 \mathrm{~kW}$; $3,114 \mathrm{~kW} ; 2,986 \mathrm{~kW}$ dan 2,804 kW jika bekerja pada temperatur evaporasi sebesar -5 ${ }^{\circ} \mathrm{C}$; dan sebesar 2,741 kW; 2,710 kW; 2,611 $\mathrm{kW}$ dan 2,445 $\mathrm{kW}$ jika bekerja pada temperatur evaporasi sebesar $-10{ }^{\circ} \mathrm{C}$.

\section{DAFTAR PUSTAKA}

[1] KOH, J. \& Zakaria, Zulkifli. (2017). Hydrocarbons as Refrigerants-A Review. ASEAN Journal on Science and Technology for Development. 34.35. 10.29037/ajstd.73

[2] Venkataiah, S., \& Rao, G.V. (2014). Analysis of Alternative Refrigerants to R22 for Air-Conditioning Applications at Various Evaporating Temperatures.

[3] Arijanto dan Ojo Kurdi (2007) Pengujian Refrigeran Hycool HCR-22 pada AC Splite sebagai pengganti Freon R-22, ROTASI, Volume 9 Nomor 2 April 2007.

[4] Ega Taqwali; HASAN, Syamsuri. Analisis Performa Refrigeran R 290 Pada Sistem AC Yang Menggunakan Accumulator Heat Exchanger. Jurnal Energi Dan Manufaktur, [S.1.],v.8,n.1, July 2015. ISSN 2541-5328.

[5] Pramudantoro, T. P. (2018) "Pengaruh Variasi Massa Pengisian R290 Sebagai Refrigeran Pengganti R22 Pada Kinerja Freezer", ReTII, 00.

[6] Parashurama, S., Saleel, C. A., Govindegowda,M. S., and Khan, S. A., (2019). Hydrocarbons as Alternative
Refrigerants in Domestic Refrigerators, International Journal of Innovative Technology and Exploring Engineering, 8: $496-501$

[7] ]Kusnandar, Kurniawan, Y., Rohmat N. Y. Analisa Performansi Mesin Pengkondisi Udara Menggunakan Refrigerant R32. Seminar Nasional Penelitian Pengabdian Masyarakat, Universitas Bangka Belitung, 194-196. 2018.

[8] Amrullah, Zuryati Djafar, Wahyu $\mathrm{H}$. Piarah. (2017), Analisa Kinerja Mesin Refrigerasi Rumah Tangga Dengan Variasi Refrigeran, Jurnal Teknologi Terapan, vol 3, No 2.

[9] Lumentut, Samuel R. (2020) Perbandingan Freon, R-32, R-22, R-410a, dan R-290, Sumber:

https://www.nationalelektronik.com/2020/0 1/perbandingan-freon-r32-r22-r410a-danr290/ diakses pada 28 Juni 2020. Pukul 10;00 PM.

[10] ASHRAE, (1990): Fundamentals Handbook, American Society of Heating, Refrigerating and Air-Contioning Enggineer, Inc. Atlanta.

[11] Priangkoso, Tabah, Nur Edy Santoso, Teguh Apriyanto dan Muhammad Dzulfikar (2018). Pengaruh Jenis Refrigerant dan Diameter Pipa Kapiler terhadap Kinerja AC Split, Jurnal Ilmiah Momentum, Vol. 14, No. 2, Oktober 2018, Hal. 39-45

[12] Mahendra, Muhammad Adrian, dan Ozkar Firdaus Homzah (2015). Analisa Perbandingan Kinerja Mesin Pendingin AC Kapasitas 2 HP menggunakan R22, R290 dan R407C. Jurnal Teknologi Pendingin dan Tata Udara Politek- nik Sekayu (PETRA) Vol 1. No, 1 Agustus 2015 hal. 11-19. 